\title{
Efficacy of TNF blockers from the perspective of growth velocity: slovak experience
}

\author{
Pavol Mrážik ${ }^{1 *}$, Elena Košková2, Veronika Vargová ${ }^{1}$ \\ From 21st European Pediatric Rheumatology (PReS) Congress \\ Belgrade, Serbia. 17-21 September 2014
}

\section{Introduction}

In patients with polyarticular course of juvenile idiopathic arthritis (JIA) both, ongoing chronic inflammation with high levels of pro-inflammatory cytokines and corticosteroid treatment, may affect linear growth adversely, potentially leading to irreversible growth retardation. Biologic treatment of JIA may have the potential to enable normal growth in children with JIA.

\section{Objectives}

To retrospectively evaluate clinical efficacy, from perspective of growth velocity as a sensitive marker of well-being in children, of biologics in children with JIA in both centers in Slovakia.

\section{Methods}

34 patients (17 girls, 17 boys) with DMARDs-resistant polyarticular JIA receiving TNF $\alpha$ blocker (28 etanercept, 6 adalimumab) + methotrexate were evaluated during their first year of biologic therapy. The mean age at antiTNF treatment initiation was 10.52 (range 2.98-17.77). Median duration of disease was 4.42 years (range 0.89 10.63), 24 patients received corticosteroids. Control group, consisted of 21 patients (12 boys, 9 girls) with polyarticular course of JIA non-responsive to NSAIDs therapy and intraarticular corticosteroid injections, was evaluated during their first year of DMARDs treatment. Same inclusion and exclusion criteria, e.g. age and Tanner staging, were applied for both groups. Growth velocity was defined by change of height in standard deviation score (SDS). A positive value $>0.1$ indicated catch-up and negative value $<-0.1$ indicated impaired growth. Values in the range -0.1 to 0.1 were labeled as "steady growth".

'Department of Paediatrics and Adolescent Medicine, Šafárik University and Children Faculty Hospital in Košice, Košice, Slovakia

Full list of author information is available at the end of the article

\section{Results}

Efficacy of combination TNF $\alpha$ blocker + MTX treatment evaluated by ACR Pediatric 30 is increasing during the first year. In time of year control 34/31/25 patients reach criteria at least for ACR Pediatric 30/50/70 respectively. The number of joints with acute arthritis decreased by $91.9 \%$ (from 309 to 25 ) compared to 91.33 \% (from 173 to 15 ) in control group. TNFa blocker + MTX combination also shows a rapid corticosteroid-sparing effect. Only 4 patients received corticosteroids at the start of DMARDs treatment in control group. Clinical response in TNF $\alpha$ blocker + MTX group was accompanied by catch-up in 18 patients, "steady growth" and impaired growth were observed in 8 cases both. Clinical response in control group was accompanied by catch-up only in 3 cases, "steady growth" and impaired growth were observed in 6 and 8 patients respectively. The difference in growth velocity was statistically significant $(0.106 \pm$ SD 0.439 vs. $-0.139 \pm \mathrm{SD} 0.385, \mathrm{t}=2.101 \mathrm{df}=53, \mathrm{p}=0.040)$.

\section{Conclusion}

Combination of TNF $\alpha$ blocker + methotrexate is highly effective in polyarticular course of DMARDs-resistant JIA. The clinical response is accompanied by an increase in growth velocity (catch-up) in most cases. The growth velocity compared with control group was on the border of statistical significance.

\section{Disclosure of interest}

None declared.

\section{Authors' details}

'Department of Paediatrics and Adolescent Medicine, Šafárik University and Children Faculty Hospital in Košice, Košice, Slovakia. ${ }^{2}$ Department of Pediatric Rheumatology, National Institute of Rheumatic Diseases, Pieštany, Slovakia. 
doi:10.1186/1546-0096-12-S1-P148

Cite this article as: Mrážik et al:: Efficacy of TNF blockers from the perspective of growth velocity: slovak experience. Pediatric Rheumatology 2014 12(Suppl 1):P148.

Submit your next manuscript to BioMed Central and take full advantage of:

- Convenient online submission

- Thorough peer review

- No space constraints or color figure charges

- Immediate publication on acceptance

- Inclusion in PubMed, CAS, Scopus and Google Scholar

- Research which is freely available for redistribution 